Joanna Zaucha

DOI: $10.33896 /$ PorJ.2020.9.5

(Uniwersytet Kardynała Stefana Wyszyńskiego, Warszawa,

e-mail: j.zaucha@uksw.edu.pl)

ORCID: 0000-0002-5766-73

\title{
O TAK ZWANYM SAMOOSZUSTWIE W ŚWIETLE ZNACZEŃ WYBRANYCH CZASOWNIKÓW
}

Przedmiotem moich rozważań będą trzy czasowniki: okłamywać się, że [p], oszukiwać się, że [p] oraz wmówić // wmawiać sobie, że [p]. Leksemy te odnosza się do sytuacji zwanej „samooszustwem”. Zapisuję to określenie w cudzysłowie. Do takiej ostrożności skłania lektura prac poświęconych zjawisku, które, jak się zwykle uważa, polega na wewnętrznie sprzecznym stanie mentalnym podmiotu. Literacka ilustracją wspomnianej sytuacji jest postać Aleksieja Karenina, który mimo wyraźnych przesłanek świadczacych o romansie Anny długo nie chce przyjać do wiadomości faktu jej wiarołomstwa. Przykład ten zaczerpnęłam $z$ pracy Kathi Beier [2019], prezentującej współczesną dyskusję filozoficzną nad pojęciem samooszustwa. ${ }^{1}$

O „samooszustwie” wspomina także Jarosław Kucharski [2014, 160-168]. Filozof przyjmuje rozbudowaną definicję „samooszustwa” autorstwa Amelii Rorty, zgodnie z która osoba oszukująca się ma świadomość niezgodności własnych przekonań, a zarazem zaprzecza owej niezgodności [Kucharski 2014, 160]. W dalszej części wywodu Kucharski przypomina prace psychologiczne, które próbuja wyjaśnić mechanizmy stojace za niemożliwym $z$ punktu widzenia zasady niesprzeczności stanem psychicznym. Nie omawia jednak krytycznie przyjętej przez siebie definicji mimo jej podwójnej sprzeczności - na poziomie rozważanych sądów oraz sądów dotyczacych pierwotnych przekonań.

W polskiej literaturze przedmiotu zagadnienie to szczegółowo przedstawia Robert Piłat w książce Powinność i samowiedza [Piłat 2013]. Autor przyjmuje stanowisko, zgodnie $z$ którym samooszustwo jest rodzajem racjonalnej manipulacji, obejmującej pojęcia, które agens wykorzystuje w formułowaniu racji wykluczających się askrypcji [Piłat 2013,

1 W dalszej części artykułu posługiwać się będę układami testowymi osnutymi wokół tołstojowskich postaci. Równie dobrze jednak można posłużyć się wypowiedzeniami opisującymi życie codzienne, typu: Wojtek okłamywał się // oszukiwał się // wmówit sobie, że sa jeszcze lody lub Okłamywał // oszukiwat się, że go nie ścigaja itd. 
118]. Zwrócenie uwagi na racje logiczne stojace za przyjęciem danej askrypcji to ważny trop dla analizy znaczenia interesujących mnie czasowników.

Prezentując współczesne ujęcia „samooszustwa”, K. Beier wskazuje na dwa główne nurty interpretowania tego zjawiska. Zgodnie $z$ pierwszą interpretacja jest ono odmiana oszustwa. Na jego strukturę składaja się dwa warunki: (1) przyjęcie przekonania, o którym agens wie, że jest fałszywe lub co do którego żywi podejrzenia, że jest fałszywe; (2) intencja lub dążenie do tego, by nie uznać fałszywości przekonania [Beier 2019, 205]. Ujmowanie stanu mentalnego właściwego A. Kareninowi $z$ tej perspektywy prowadzi do tzw. statycznego paradoksu samooszustwa. Polega on na tym, że tej samej osobie przypisuje się dwa wykluczające się przekonania, np. „Anna ma romans” i „Anna nie ma romansu”. W oczywisty sposób narusza to zasadę niesprzeczności.

Filozofowie starają się przezwyciężyć paradoks wynikający $z$ naruszenia zasady niesprzeczności, interpretujac „samooszustwo” jako rodzaj działania irracjonalnego. Takie, antyredukcjonistyczne, ujęcie proponuje m.in. Donald Davidson [2004]. Zdaniem filozofa podmiot // agens dysponuje wieloma odrębnymi zbiorami przekonań. Ich spójność zachowana jest wyłącznie w obrębie poszczególnych zbiorów, niekoniecznie zaś między nimi [Davidson 2004, 210-211]. Zgodnie $z$ ujęciem Davidsona ktoś, kto podlega „samooszustwu”, podejmuje działania, by nabrać przekonania przeciwnego niż to, które jego zdaniem jest prawdziwe [Davidson 2004, 208], wybierając tym samym słabe uzasadnienie sadu zamiast sumy dowodów przemawiających za jego dopełnieniem logicznym, a znajdujących się w konkurującym zbiorze przekonań. W podobnym duchu „autokłamstwo” ujmował Wojciech Chudy [2003]. Filozof wyróżnił trzy plany poznania: spostrzeżeniowy, refleksyjny „typu aktowego” oraz „typu peryferyjnego” [Chudy 2003, 418-419]. Zdaniem W. Chudego doraźny interes skłania autokłamcę do zepchnięcia poza świadomość tych spostrzeżeń i konstatacji (refleksje typu aktowego), które sa sprzeczne $z$ preferowanym stwierdzeniem.

Rozważając właściwości semantyczne kilku czasowników z grupy predykatów implikujacych fałsz, będę chciała zderzyć konkurujące interpretacje „samooszustwa” $z$ danymi językowymi. Wcześniej przypomnę rozróżnienia pojęciowe istotne dla opisu leksemów tej klasy.

\section{PODSTAWOWE ROZRÓŻNIENIA TEORETYCZNE}

Wiele problemów logicznych wiąanych $z$ kłamstwem w filozoficznej literaturze przedmiotu bierze się $z$ próby opisu tego fenomenu jako interakcji, w którą zaangażowane są dwie osoby: kłamca // oszust oraz jego ofiara. Filozofowie nie dostrzegaja roli „przeźroczystego” metanadawcy. $\mathrm{W}$ istocie jest on stałym punktem odniesienia, kiedy mowa o wprowadza- 
nym do dyskursu fałszu. Na ogół to właśnie na metanadawcy spoczywa ciężar wskazania fałszywej askrypcji.

Obecność i rolę kontrolera-nadawcy w treści czasowników epistemicznych opisała Magdalena Danielewiczowa [2002, 76-86]. Konfrontacja wiedzy podmiotu epistemicznego $z$ wiedza kontrolera-nadawcy, czyli osoby używającej określonego predykatu, stanowi oś rozróżnień w obrębie klasy predykatów epistemicznych. Badaczka zwraca uwagę, że charakterystyka wiedzy kontrolera-nadawcy jest elementem treści różnych grup wyrażeń, w szczególności czasowników wyrażających ocenę, takich jak przeceniać [kogoś/coś], wyolbrzymiać [coś], idealizować [kogoś]. Jest ona istotna również w opisie znaczenia eksponentów fałszu. Zdaniem lingwistki czasownik okłamywać się, że [p] implikuje koniunkcję zarówno wiedzy kontrolera-nadawcy, jak i agensa, iż nie zachodzi stan rzeczy wyrażony w uzupełnieniu propozycjonalnym. Natomiast czasowniki $ł u-$ dzić się, że [p], wmawiać sobie, że[p], mamić się, że [p], zwodzić się, że [p] przesadzaja wiedzę metanadawcy, że stan rzeczy $p$ nie zachodzi oraz brak wiedzy agensa co do zachodzenia stanu rzeczy $p$ [por. Danielewiczowa 2002, 83-84].

Drugim filarem opisu wykładników „samooszustwa” jest rozróżnienie wprowadzone przez A. Bogusławskiego. Jest ono prezentowane i rozwijane w licznych pracach uczonego [Bogusławski 2004; 2005; 2007; 2008]. Mam na myśli dystynkcję między mówieniem cytacyjnym i asertorycznym. Tylko to drugie, którego wykładnikiem jest przyjmujacy na siebie akcent logiczny czasownik powiedzieć, że, stanowi deklarację agensa co do własnej wiedzy. Czasowniki okłamywać się, że [p], oszukiwać się, $\dot{z} e$ [p] oraz wmówić / / wmawiać sobie, że [p] zawieraja w swej treści pojęcie mówienia cytacyjnego. Żadnej z czynności wskazywanych przez te czasowniki agens i pacjens w jednej osobie nie mógł wykonywać, milczac. ${ }^{2}$ Zarazem jednak $z$ perspektywy metanadawcy akt mowny agensa nie może być traktowany jako mówienie asertoryczne, czyli oparte na jego wiedzy. Przede wszystkim dlatego, że metanadawca wie, że układy słowne, którymi posługuje się agens, nie maja pokrycia w rzeczywistości. Co więcej, przesądza on również i to, że osoba oszukująca się miała dostęp do faktów, które przemawiaja przeciw stwierdzeniu kompatybilnemu $z$ jej działaniem.

2 Piszac o wykluczaniu okłamywania się i milczenia mam na myśli dowolny typ mówienia - w tym również tzw. mowę wewnętrzna. $\mathrm{W}$ moim przekonaniu nie można okłamywać się, nie dokonując aktów mownych. Nie muszą być one jednak uzewnętrzniane. Jak słusznie wskazywano w recenzji, zdanie typu: Aleksiej Karenin okłamywał się, że Anna jest mu wierna, nic nie mówiąc można uważać za niesprzeczne. Dzieje się tak jednak wyłącznie przy zawężonej interpretacji, w której Aleksiej nic nie mówił do nikogo poza soba samym. W o wiele mniejszym stopniu do wprowadzania nadwyżek interpretacyjnych skłania układ: * $W$ milczeniu Aleksiej okłamywał się, że Anna jest mu wierna. 
Trzeci z ogólniejszych problemów istotnych w opisie wykładników „samooszustwa" to kwestia ustalenia statusu elementów sie // sobie pojawiających się przy czasownikach. W dalszym wywodzie staram się pokazać, że jest to integralny element odpowiednich jednostek. Głównym argumentem za takim przesądzeniem jest różnica logiczna niesprowadzalna do różnic między 'ktoś' a 'ja', która daje się zauważyć w kontekście wykładników „samooszustwa”. Warto jednak mieć na uwadze również fakt seryjności niektórych układów adresatywnych ${ }^{3}$ oraz analogicznych konstrukcji z segmentem sobie // siebie. W parach: powtarzat bratu - powtarzal sobie, odpowiedział bratu - odpowiedział sobie, krzywdził brata - krzywdzit siebie, wyttumaczył bratu - wyttumaczył sobie stosunek zaimka i rzeczownika do predykatu jest identyczny. Analogia nie jest zachowana w układach: przypomniał bratu-przypomniał sobie, uświadomił bratu - uświadomił sobie oraz, jak chcę twierdzić, w układzie: wmówił bratu - wmówił sobie.

\section{OKEAMYWAĆ SIE, $\dot{Z} E$ [P]}

Jako jeden $z$ pierwszych leksemów opisujących powieściową sytuację Aleksieja Karenina przychodzi na myśl czasownik okłamywać się, $\dot{z} e$ [p]. Możemy powiedzieć, że Karenin przez długi czas okłamywał się, że jego żona nie ma romansu. Załóżmy jednak, że nie tylko sam Aleksiej się okłamywał, ale i Anna okłamywała męża. Czy w obu wypadkach mamy do czynienia $z$ tą sama jednostka języka? Czy element się przy czasowniku okłamywać to wykładnik zaimka zwrotnego realizującego pozycję przy czasowniku czy część jednostki czasownikowej? Pytanie o kształt i granice jednostki leksykalnej i tożsamość jej treści w układzie autorefleksywnym i adresatywnym odbija zarysowaną we wstępie kontrowersję filozoficzną. Niewykluczone, że utożsamienie samooszustwa $z$ kłamstwem na gruncie filozoficznym ma swoje źródło w podobieństwie formalnym wykładników opisujących sytuację czyjegoś kłamstwa $z$ jednej strony oraz sytuacje przyjęcia nieprawdziwej askrypcji jako podstawy swojego działania $z$ drugiej.

Po pierwsze, trzeba zauważyć, że w kontekście refleksywnym nieużywana jest forma okłamał(a). Nie powiemy: *Aleksiej okłamał się, że Anna nie ma romansu (vs ${ }^{+}$Anna okłamała Aleksieja, że nie ma romansu). ${ }^{4}$ Czynność nakierowana na samego siebie nie może być wyrażona

3 Pojęcia adresatywności używam za Małgorzata Marcjanik [1987, 15-16]. Przeciwstawiam je autorefleksywności. Tym ostatnim pojęciem obejmuję wypadki, w których pacjensem (odbiorca komunikatu) jest sam nadawca / / agens.

4 Teza ta znajduje odbicie w opisie zamieszczonym w ISJP [2000]. Inaczej jest w WSJP [http://wsjp.pl/ - 23.05.2020 r.]. Słownik wyodrębnia jednostkę okłamać się w sensie autorefleksywnym. Niemniej wypowiedź zamieszczona jako 
forma dokonana czasownika. Natomiast akt adresowany do innego odbiorcy daje się opisać za pomoca dowolnej z form. Różnica ta stanowi jedna $z$ przesłanek przemawiających za odrębnością predykatu okłamywać się, że [p].

Inną różnicę można dostrzec, negując użycie obu predykatów. Zanegowanie predykatu autorefleksywnego (przy akcencie zdaniowym padającym na ten właśnie predykat) przesądza o fałszywości zdania podrzędnego. Ze zdania: Aleksiej nie oktamywat się, że Anna nie ma romansu wnioskujemy, że Aleksiej wiedział, że Anna ma romans. Negacja czasownika adresatywnego także implikuje fałszywość zdania podrzędnego (ze zdania Anna nie okłamywata męża, że nie ma romansu wynika, że Anna ma romans), nie przesadza jednak niczego co do wiedzy adresata. Jeśli Anna nie okłamywała męża, że nie ma romansu, nie musiała mówić mu prawdy. Aleksiej wciąż może tkwić w błędnym przekonaniu o wierności żony.

Fakt, który warto odnotować, zderzając ze sobą użycia adresatywne i autorefleksywne, to przynależność obu predykatów do klasy czasowników mówienia. Żaden $z$ nich nie może być użyty w połączeniu $z$ imiesłowem milczac lub $z$ określeniem $w$ milczeniu (por. wyżej). Wyrażenie okłamywać w obu rozważanych typach kontekstów nie łączy się też $\mathrm{w}$ spójną całość informacyjną $z$ określeniami fonicznego sposobu wyrazu. ${ }^{5}$ Zdania: ?Anna cicho // półgłosem okłamywała męża, że nie ma romansu i ?Aleksiej cicho // półgłosem okłamywał się, że Anna nie ma romansu nie sa wyraźnie dewiacyjne. Predykaty użyte w przytoczonych zdaniach nie wykluczaja możliwości brzmieniowego scharakteryzowania czynności mownej. Niemniej informacja o formie dokonywania aktu, o którym mowa, nie współgra $z$ istota orzekania o fałszu. W efekcie otrzymujemy wypowiedzenie niespójne tematycznie.

Zasadnicza różnica między okłamać // okłamywać adresatywnym i okłamywać autorefleksywnym wiąże się ze stosunkiem treściowym między tymi wyrażeniami a jednostka skłamać, że [p]. Adresatywne okłamywać implikuje kłamstwo, natomiast jednostka autorefleksywna - nie, por. *Anna okłamywała Aleksieja, że nie ma romansu, ale mu nie skłamała vs ${ }^{+}$Aleksiej okłamywał się, że Anna nie ma romansu, choć nikomu nie skłamał. Czasownik okłamać [kogoś], że [p] implikuje skłamać, że [p]. Nie zachodzi natomiast implikacja w druga stronę. Możemy powiedzieć: +Anna skłamała, że nie ma romansu, ale nie udało jej się okłamać Aleksieja.

ilustracja użycia jednostki (Po raz kolejny okłamałam się, że wszystko jest $w$ porządku. Ciagle zawodzę siebie) może bronić się chyba tylko jako celowe naruszenie normy językowej zastosowane dla efektu literackiego.

5 Zbigniew Greń [1994] uważa tę właściwość za główny wyznacznik klasy czasowników mówienia w sensie ścisłym. 
Ze względu na tę różnicę znamienny jest sposób użycia obu jednostek przez Olafa Tumskiego w książce Dwunasta warstwa. Znajdujemy tam następujący fragment: „Leżąc w łóżku z Cany, okłamywał ja, okłamywał siebie, krzywdził Florencję [imię żeńskie - J.Z.]. No może był margines prawdy" [Tumski 2012, 170]. Sekwencja składająca się z wyrażeń okłamywał i krzywdził służy podkreśleniu negatywnej oceny stanu rzeczy, jakim jest niewierność głównego bohatera. Pełni jednak jeszcze jedną funkcję: ratuje wypowiedź przed semantyczna niespójnością. Intuicja autora zdania, by nie łączyć obu jednostek zawierających wyrażenie okłamywał, jest niezwykle trafna. O. Tumski osobno opisuje okłamywanie skierowane przez agensa do samego siebie, osobno - działania adresowane do kogoś innego (do Cany i Florencji). Zauważmy, że okłamywanie kogoś zakłada rozeznanie agensa co do faktycznego stanu rzeczy. Ktoś, kto okłamuje siebie co do czegoś, nie spełnia w pewnym sensie warunków wstępnych tego, by móc okłamać innych. Zatem zastosowany przez autora porządek jest bardziej naturalny niż możliwość odmiennego ukształtowania elementów sekwencji. $Z$ tego samego względu, stosując skrót tekstowy, lepiej powiedzieć: On okłamywał Sieriożę i siebie niż On okłamywał siebie i Sieriożę.

O charakterystycznym ustosunkowaniu okłamywania adresatywnego i autrefleksywnego świadczy możliwość orzekania jednej czynności przy jednoczesnym zanegowaniu drugiej predykacji: ${ }^{+}$Aleksiej okłamywał Sierioże, że Anna nie ma romansu, podczas gdy sam pogodził sie ze smutna prawda i nie okłamywał się. Odwrotny układ negacyjny nie jest możliwy: *Aleksiej okłamywał się, że Anna nie ma romansu, ale dziecku powiedziat prawdę.

Wszystko to wzmacnia przekonanie o odrębności treściowej jednostek języka zawierających wyrażenie okłamywać. ${ }^{6}$ Znamienny w tym względzie jest, jak pisałam, stosunek między nimi a sensem jednostki [ktoś skłamał, że [p], a także niekompatybilność okłamywania autorefleksywnego i okłamywania adresatywnego ze względu na wprowadzana przez obie jednostki odmienna charakterystykę wiedzy agensa. Obserwacja różnic semantycznych i formalnych między różnymi wystapieniami wyrażenia okłamywał (a) skłania do wyodrębnienia dwóch jednostek języka: ktoś $_{i}$ okłamywał sie // siebie, że [p] oraz ktośs okłamał // okłamywat $k_{\text {kogos }} \dot{s \neq i}_{i}, \dot{z} e[p]$. Jest to rozwiąanie dominujące w polskim opisie leksykograficznym. Wygląda więc na to, że polszczyzna „wspiera” tezę antyredukcjonistyczną w odniesieniu do istoty „samooszustwa”.

6 W swoim wywodzie pomijam ważną kwestię ograniczeń selekcyjnych argumentu zdarzeniowego w kontekście rozważanych predykatów. Właściwości te nie różnicują interesujących mnie jednostek. Wszystkie one wykluczają w tej pozycji tautologie i kontrtautologie. Układy ze zdaniami podrzędnymi w oczywisty sposób prawdziwymi (np. Ziemia krą̇y wokót Słońca) nie brzmia w kontekstach rozważanych jednostek najlepiej. Nie sa jednak obarczone wewnętrzna sprzecznościa. 
Jednomyślność leksykografów co do odrębności jednostek nie idzie $\mathrm{w}$ parze $z$ identycznościa hipotez co do treści wyodrębnionych bytów językowych. ISJP wyróżnia dwie jednostki zawierające wyraz okłamać. Pierwsza $z$ nich (o sensie adresatywnym) jest definiowana za pomoca zależności: „Jeśli ktoś okłamał nas, to świadomie powiedział nam nieprawdę" [ISJP 2000, 1150]. ${ }^{7}$ Jako kształt drugiej $z$ jednostek (o sensie autorefleksywnym) słownik podaje wariantywne formy: okłamywat sie // samego siebie // sam siebie. Zgodnie z zamieszczona glosa treść tej jednostki sprowadza się do braku chęci uznania za prawdę czegoś prawdziwego, ale niewygodnego lub przykrego. WSJP także wyróżnia jednostkę autorefleksywną, choć jako jej kształt niezbyt szczęśliwie podaje okłamać się. W słowniku zamieszczono następująca definicję: „wywoływać u siebie przekonanie, że coś jest prawda, choć tak nie jest". ${ }^{8}$ Sens jednostki adresatywnej słownik opisuje inaczej, mianowicie: „przez świadome powiedzenie nieprawdy wywołać u kogoś powstanie mylnego przekonania albo niepoprawnego rozumowania na dany temat". Obie jednostki rozróżnia także SJPD. Dla oddania sensu okłamać adresatywnego w słowniku użyta jest formuła: „kłamiąc, oszukać kogoś, wprowadzić kogo w bład”. Natomiast znaczenie jednostki autorefleksywnej definiowane jest za pomoca czasownika wmówić: „wmówić w siebie coś, co nie jest prawda”. $Z$ kolei definicja zamieszczona w USJP zbiera niejako wcześniejsze propozycje. Wydzielajacc jednostkę autorefleksywną, redaktorzy słownika opisuja ją następująco: „skłaniać się do uznania za prawdę czegoś nieprawdziwego, umacniać się w niesłusznym przekonaniu o czymś, okłamywać samego siebie, wmawiać coś w siebie" [USJP, https://sjp.pwn.pl - dostęp: 02.09.2020 r.].

Różnorodność definicji pozostawia czytelnikowi wybór opisu stanu ducha Aleksieja Karenina: Aleksiej Karenin nie chciał uznać za prawdę niewygodnego lub przykrego dla siebie faktu, że Anna ma romans, choć było to prawda [ISJP] badź: Aleksiej Karenin wywoływał u siebie przekonanie, że prawdą jest, iż Anna nie ma romansu, choć go miała [WSJP], bądź: Aleksiej Karenin wmawiał w siebie, że Anna nie ma romansu, co nie było prawda [SJPD]. Mógł też tylko skłaniać się do tego, by uznać za prawdę to, że Anna nie ma romansu lub umacniać się w niesłusznym przekonaniu o jej wierności [USJP].

7 Nawiasem mówiac, tę sama glosę znajdujemy przy opisie czasownika skłamać. Sugeruje to synonimiczność obu jednostek.

8 Sformułowanie zamieszczone w słowniku jest nieprecyzyjne. Nie uwzględnia faktu, że jednostka może być odniesiona do kogoś innego niż osoba używająca jednostki. Tymczasem użycie zaimka siebie zawęża zakres odniesienia czasownika do użyć pierwszoosobowych. Niefortunność tego zapisu pokazuje użyteczność przyjęcia formy trzecioosobowej czasownika (tam gdzie ona istnieje) jako bazy dla opisu sensu, na co wielokrotnie zwracał uwage A. Bogusławski w licznych swoich pracach dotyczących leksykografii [m.in. Bogusławski 1988; Bogusławski, Danielewiczowa 2005]. 
Propozycje słownikowe nie wykluczaja się wzajemne, ale nie są też tożsame logicznie. Opis z ISJP podkreśla wolitywny element „samooszustwa”. Definicja w WSJP koncentruje się na aspekcie epistemicznym, a opis SJPD utożsamia okłamywanie autorefleksywne $z$ wmawianiem sobie czegoś dodatkowo (i niepotrzebnie zarazem - ponieważ wynika to $z$ sensu użytego w definiensie wyrażenia), podkreślając sprzeczność między treścia propozycjonalna ujęta $\mathrm{w}$ zdaniu podrzędnym a faktycznym stanem rzeczy. Najostrożniej sformułowana jest część definicji zamieszczonej w USJP.

Wobec różnorodności definicyjnej powstaje pytanie o to, która z przedstawionych możliwości jest tą właściwą. Co rzeczywiście składa się na wewnętrzną logike jednostki [ktoś.] okłamuje się // siebie, że [p]?

Niech do weryfikacji zastanych hipotez posłuża nam układy testowe osnute wokół historii Anny Kareniny. Ze zdania Aleksiej okłamywał się, że Anna nie ma romansu nie wynika, że nie chciał uznać za prawdę czegoś niewygodnego // przykrego dla siebie. Zdanie: Aleksiej okłamywat się, że Anna nie ma romansu, mimo że chcial // był gotów uznać nawet te przykra prawdę nie jest sprzeczne. Spójność przytoczonego układu wyrażeniowego jest zachowana dzięki różnicy zachodzącej między wola działania a samym działaniem. Nie sa to akty tożsame. Chęć zdobycia jakiejś informacji nie oznacza jej zdobycia. To, czy Karenin chce uświadomić sobie sytuację, w której się znajduje, czy też nie, nie jest tym samym, co uświadomienie sobie owej sytuacji. Co więcej, ponieważ okłamywanie się wiąże się $z$ wyrządzaniem krzywdy samemu sobie, jego nieintencjonalność jest bardziej naturalna. Jeśli jednak postawimy sprawę na ostrzu noża, zderzając okłamywanie się z samym uznawaniem czegoś za prawdę ( $z$ pominięciem elementu wolitywnego), efekt będzie inny. Zdanie: *Aleksiej okłamywał się, że Anna nie ma romansu, choć uznawał te przykra prawde jest sprzeczne. Najbliżej do uchwycenia tej właściwości jest opisowi zawartemu w USJP.

Podobny efekt zaobserwujemy, badając zależność logiczną między jednostka autorefleksywna a przytoczonym wyżej definiensem zaproponowanym w WSJP: *Aleksy okłamywał sie, że Anna nie ma romansu, ale nie wywołał u siebie przekonania, że Anna jest mu wierna.

Stosunek między okłamywać się i wmawiać sobie coś, przywołany w definicji z SJPD i USJP, jest trudniejszy do zdiagnozowania. Czy Aleksiej mógł okłamywać się, że Anna nie ma romansu, nie wmawiając sobie tego? Nie wygląda na to, żeby taki układ był sprzeczny. Ktoś, kto się okłamuje, nie musi jednocześnie systematycznie powtarzać (choćby w myśli) nieprawdziwej askrypcji. Nie musi więc w mawiać sobie tego, co do czego się skłania. Czy można wobec tego wmawiać sobie coś, nie okłamując się? Wydaje się, że i taki układ jest możliwy, o ile mamy do czynienia $z$ forma niedokonana czasownika. Jeśli jednak powiemy, że Aleksiej wmówił sobie, że Anna jest mu wierna, to pod groźbą sprzeczności nie możemy utrzymywać, że nie okłamywał się co do wierności żony. 
Ustalenie stosunków logicznych między 'wmówieniem sobie czegoś' i 'okłamywaniem się' nie wystarcza do przybliżenia treści interesującej nas jednostki. Wciąż nie wiemy, czym jest okłamywanie się. Czego o podmiocie i jego działaniach możemy się dowiedzieć, przypisując mu 'okłamywanie się’?

Ślady prowadzace do wykrycia elementów treści predykatu $k t o s_{i}$ okłamuje się, że [p] pojawiały się już w rozważaniach dotyczacych wyodrębnienia tej jednostki. Za jej pomocą orzekamy o osobie, której stan wiedzy i działania sa diagnozowane przez kontrolera-nadawcę. Istotnym elementem struktury semantycznej jest też treść stanowiąca przedmiot wiedzy oraz jej uzupełnienie logiczne.

Jedną $z$ tez co do treści okłamywać się, że [p] zgłosiła M. Danielewiczowa [2002, 83-84]. Zgodnie $z$ proponowanym zapisem interesująca nas jednostka implikuje wiedzę metanadawcy oraz agensa, że nie zachodzi stan rzeczy wskazany w zdaniu podrzędnym wprowadzanym przez czasownik. Wygląda jednak na to, że układ, w którym orzekane jest czyjeś okłamywanie się oraz brak wiedzy co do określonego stanu rzeczy, jest niesprzeczny: ${ }^{+}$Aleksiej okłamywał się, że Anna jest mu wierna, nie wiedzac, czy go zdradza. Osoba okłamujaca się nie musi wiedzieć, że nie zachodzi to, o czym mowa w zdaniu podrzędnym. Tę wiedzę ma kontroler-nadawca. Nie jest jednak tak, iżby agens nie wiedział niczego w zwiazku $z$ tematyzowana askrypcja. Wskazuje na to sprzeczność następującego układu: *Aleksiej okłamywał się, że Anna nie ma romansu, bo też nic na to nie wskazywało. Wiedza podmiotu dotyczy zatem, tak jak wskazywał na to Robert Piłat [2013, 118], racji treści wskazanej w zdaniu podrzędnym. Dlatego właśnie konteksty składniowe, które ujmują informacje zbieżne $z$ dopełnieniem logicznym przyłączanej askrypcji, należą do najlepszych ilustracji użycia jednostki autorefleksywnej: ${ }^{+}$Wiedzac, że Anna spotyka się $z$ Wrońskim, Aleksiej okłamywał się, że żona nie ma romansu i ${ }^{+}$Stwierdziwszy, że Anna spotyka się z Wrońskim, Aleksiej okłamywał się, że nie maja romansu. O przekonaniu metanadawcy co do dostępności adekwatnego opisu rzeczywistości agensowi świadczy również sprzeczność kontekstu: *Aleksiej okłamywał się, że Anna jest mu wierna, nie mógł jednak wiedzieć, że zdradza go z Wrońskim. Wygląda też na to, że można okłamywać się, wiedząc, jak się sprawy maja.. Świadczy o tym niesprzeczność następujących kontekstów: ${ }^{+}$Aleksiej okłamywał się, że Anna nie ma romansu, choć wiedziat, że zdradziła go $z$ Wrońskim oraz ${ }^{+}$Stwierdziwszy, że Anna zdradziła go z Wrońskim, Aleksiej nadal okłamywał się, że jest mu wierna. ${ }^{9}$

9 Jeszcze wyraźniej niesprzeczność między okłamywaniem się co do pewnego faktu i wiedzą o jego zachodzeniu widać w zdaniach opisujących życie codzienne, por. Okłamywał się, że go nie ścigaja, choć wiedział, że jest inaczej lub Okłamywał się, że jest inaczej, stwierdziwszy, że go ścigają. 
Jaki zatem obraz implikacji właściwych rozważanej jednostce języka wyłania się z układów testowych? Osoba okłamująca się nie musi mieć wiedzy co do wskazanego w uzupełnieniu składniowym stanu rzeczy. Tę wiedzę ma metanadawca. Niemniej okłamujący się ma wiedzę co do pewnych warunków zajścia zdarzenia // stanu rzeczy, o które chodzi. Może także po prostu wiedzieć, jak jest i mimo to się okłamywać. Użycie czasownika przesadza jedynie to, że zdaniem metanadawcy okłamujący się mógl wiedzieć, jak się sprawy maja. Jeśli wie, że $p$ nie zachodzi, to $z$ sobie wiadomych względów nie jest gotów na powiedzenie prawdy.

Obraz ten odpowiada tym poszukiwaniom filozoficznym, które ujmuja "samooszustwa” jako irracjonalne działanie agensa. Intrygująca filozofów sprzeczność bezpośrednia nie musi charakteryzować podmiotu okłamującego siebie. Zachodzi ona między askrypcja, do której skłania się podmiot poprzez odrzucenie możliwości powiedzenia prawdy, a przedmiotem wiedzy metanadawcy. Metanadawca wskazuje także na wiedzę agensa o okolicznościach skłaniających do przyjęcia stwierdzenia przeciwnego niż wyrażone w zdaniu podrzędnym.

Jak mogliśmy się przekonać, fałsz zdania przyłączonego w dopełnieniu składniowym jednostki autorefleksywnej oraz implikacja o mownym charakterze aktu okłamywania się sa presuponowane przez interesująca nas jednostkę. W części rematycznej struktury znaczeniowej znajdzie się informacja o wiedzy podmiotu (co do zachodzenia warunków koniecznych stanu rzeczy ujętym w zdaniu podrzędnym) oraz braku dyspozycji do wyboru odpowiedniej askrypcji. W tej części struktury znaczeniowej znajdzie się również informacja o ocenie sytuacji, o której mowa, z perspektywy metanadawcy. Wskazuje na to sprzeczność zdania: *Aleksiej słusznie postępował okłamując się, że Anna nie ma romansu.

\section{OSZUKIWAĆ SIE, $\dot{Z} E$ [P]}

Drugim polskim czasownikiem, który równie dobrze może posłużyć do opisu sytuacji Aleksieja Karenina, jest oszukiwać się, że [p]. Wyrażenie to wykazuje podobny defektywizm co autorefleksywne okłamywać, jeśli chodzi o możliwość użycia formy dokonanej, por. *Aleksiej Karenin oszukał się, że Anna nie ma romansu. Jednostka ta została wyodrębniona w ISJP i opatrzona ta samą definicja co okłamywać się, że [p]. Także WSJP odnotowuje jednostkę o kształcie oszukiwać się. Opis znaczenia czasownika różni się jednak od opisu okłamać się, por.: „przekonać siebie samego, że coś jest prawda, choć tak nie jest". Definicja jest uproszczeniem obszerniejszej glosy zamieszczonej w opisie pierwszej $z$ jednostek opisanych $\mathrm{w}$ haśle oszukiwać. Bardziej rozbudowana wersja brzmi: „w celu osiagnięcia korzyści powodować powstanie u kogoś przekonania, że coś jest prawdziwe lub zgodne $z$ przyjętymi regułami, podczas gdy takie nie jest”. Redakcja słownika słusznie zrezygnowała 
z elementu mówienia o korzyści zwiąanej z oszustwem w opisie oszukiwać się. SJPD przybliża znaczenie czasownika oszukać z elementem się za pomoca szeregu: „zawieść się, omylić się, zostać oszukanym.” Z kolei USJP oddaje sens leksemu następująco: „okłamać (okłamywać) samego siebie, nie przyjać (nie przyjmować) do wiadomości prawdy”.

Przegląd rozwiazań leksykograficznych nasuwa wiele pytań. Jak się ma oszukiwać się, że [p] do okłamywać się, że [p], a także do przekonać siebie samego, że coś jest prawdą? Na pierwszy rzut oka trudno doszukać się różnicy znaczeniowej między oszukiwać się, że [p] i okłamywać się, że [p]. Ze zdania: Aleksiej okłamywał się, że Anna nie ma romansu wynika zdanie: Aleksiej oszukiwał się, że Anna nie ma romansu i na odwrót. Żaden $z$ rozważanych czasowników nie implikuje natomiast przekonywania samego siebie do czegoś: ${ }^{+}$Aleksiej okłamywał // oszukiwał się, że Anna nie ma romansu, ale nie przekonywat samego siebie, że jest to prawda. Przekonywanie kogoś (lub siebie) do czegoś to proces wieloetapowy, wymagajacy rozważenia racji dwóch wykluczajacych się stwierdzeń. Osoba okłamująca // oszukująca się nie podejmuje takiego wysiłku. Przeciwnie - ktoś taki jest gotów wybrać stwierdzenie zawierające askrypcję niespójna z jego dotychczasowa wiedzą. Słuszna wydaje się zatem strategia ISJP, aby obie jednostki definiować jednakowo, zwłaszcza że rozkład wiedzy podmiotu i metanadawcy w strukturze treści obu predykatów jest identyczny. Analogicznie do okłamywać się autorefleksywne oszukiwać się nie przesądza wiedzy podmiotu o fałszu askrypcji ujmowanej w zdaniu podrzędnym, choć ją dopuszcza. Różnica między okłamywać się, że [p] i oszukiwać się, że [p] widoczna jest w części presupozycyjnej struktury znaczeniowej obu jednostek. W wypadku okłamywania się jest to implikacja mówiąca o braku gotowości powiedzenia czegoś prawdziwego. Wyróżnikiem treści predykatu oszukiwać się, że $[p]$ jest za to dowolne działanie, które prowadzi do gotowości powiedzenia fałszu. Dlatego może istnieć wiele sposobów, w których dokonuje się oszukiwanie się. Przejawem wspomnianej różnicy semantycznej między oboma jednostkami jest sprzeczność następujacych układów: ${ }^{+}$Aleksiej, chwytajac się różnych metod // na różne sposoby oszukiwał się, że Anna nie ma romansu vs * Aleksiej, chwytajac się różnych metod // na różne sposoby okłamywał się, że Anna nie ma romansu.

Zbierając obserwacje co do właściwości jednostek [ktoś.] okłamuje się, $\dot{z} e[p]$ i [ktos. $\dot{s}_{i}$ oszukuje się, że [p], wypada stwierdzić, że wyrażenia te różnia się funkcjonalnie i formalnie od swoich odpowiedników adresatywnych. Ich cecha charakterystyczna jest presuponowanie fałszu askrypcji ujętej w przyłączonym zdaniu podrzędnym. Obie jednostki presuponuja także wiedzę metanadawcy co do stanu rzeczy wyróżnionego w przyłą-

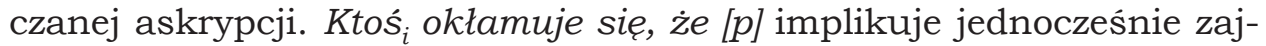
ście nieasertorycznego aktu mownego. Szersza zakresowo jednostka $k$ toś oszukuje się, że [p] nie wyklucza żadnego ze sposobów uzasadniania wyboru fałszu. Do rematycznej części znaczenia obu analizowanych wyra- 
żeń należy informacja o braku wiedzy podmiotu co do zachodzenia stanu rzeczy ujętego w dołączonej askrypcji oraz o gotowości wyboru tego $z$ wykluczających się zdań, o którym metanadawca wie, że jest nieprawdziwe oraz które nie jest spójne $z$ wcześniejszą wiedza podmiotu, obejmująca warunki konieczne stanu rzeczy, o którym mowa.

Biorąc pod uwagę rozróżnienia leksykalne właściwe polszczyźnie, trzeba przyznać rację antyredukcjonistyczemu podejściu do „samooszustwa”. Odrębność jednostek, brak możliwości użycia formy dokonanej oraz brak implikacji o wiedzy podmiotu dotyczacej askrypcji, o której mowa, skłaniają do ujmowania „samooszustwa” jako zjawiska swoistego. Patrzac z perspektywy rozróżnień leksykalnych polszczyzny, „samooszustwo" lub "samookłamywanie” to rodzaj ryzykownego wyboru między askrypcjami, wyboru nieuwzględniającego stanu wiedzy podmiotu.

\section{WMÓWIĆ // WMAWIAĆ [KOMUŚ], ŻE [P]}

Jako ostatni czasownik opisujacy sytuację określaną w terminologii filozoficznej jako „samooszustwo" omówię jednostkę wmówić // wmawiać sobie, że [p]. Czasownik ten różni się pod pewnymi względami od okłamywać się, że [p] i oszukiwać się, że [p], chociaż ma też z nimi wiele wspólnego.

Pierwsza różnica związana jest $z$ funkcjonowaniem form aspektowych. Tym razem w kontekście autorefleksywnym może pojawić się również forma dokonana czasownika. Opisując modelowa sytuację Karenina, możemy powiedzieć zarówno, że w mó wił s o bi e, że Anna nie ma romansu, jak i że w m a w i $ł$ s o b i e, że Anna nie ma romansu. Co istotne, obie formy czasownika zachowuja różnicę sensów typowa dla par aspektowych. Druga różnica uwidacznia się przy badaniu możliwości uszeregowania argumentów wskazujących na adresata wmawiania czegoś. Nie jest ono dowolne. W wypadku omawianego predykatu preferowana jest inna kolejność niż przy okłamywać // oszukiwać się, że [p]. Układ: Aleksiej wmówił sobie $i$ Sierioży, że Anna nie ma romansu brzmi lepiej niż zdanie: Aleksiej wmówił Sierioży i sobie, że Anna nie ma romansu. O preferencji decyduje naturalna kolejność biegu spraw oraz właściwości spójnika $i$ [por. Wajszczuk 1997, 263-282]. Dysponując wiedzą na określony temat, agens najpierw sam decyduje się na stwierdzenie przeciwne względem tego, co wie, a następnie zmierza do tego, by fałsz przyjął jego rozmówca.

Istotna różnica w stosunku do okłamywać się, że [p] i oszukiwać się, $\dot{z} e$ [p] związana $\mathrm{z}$ użyciem wmówić // wmawiać sobie, że [p] jest brak presupozycji mówiącej o fałszu askrypcji ujętej w zdaniu podrzędnym. Przesądzenie fałszywości wmówionej treści dokonuje się w części rematycznej struktury znaczeniowej predykatu. Ze zdania zaprzeczajacego wmówieniu sobie czegoś, w którym akcent logiczny pada na czasownik 
zdania głównego, nie wynika zaprzeczenie treści zdania podrzędnego, np. ze stwierdzenia: Aleksiej nie wmówił sobie, że Anna nie ma romansu nie wynika, że Anna ma romans. Wręcz przeciwnie - forma przytoczonej wypowiedzi (na zasadzie pragmatycznej) skłania ku przekonaniu, że jest tak, jak głosi zdanie podrzędne. Rozumujemy wtedy, że skoro ktoś mówi, że Aleksiej nie wmówił sobie, że Anna jest mu wierna, to pewnie dlatego, że nie musiał sobie niczego wmawiać, bo jego żona nie ma romansu.

Autorefleksywne wmówić, podobnie jak okłamywać się, że [p], nie implikuje wiedzy podmiotu co do stanu rzeczy, o którym mowa, por.: +Aleksiej wmówit // wmawiał sobie, że Anna nie ma romansu, choć nie wiedziat, czy go ma. Jednostka ta, podobnie jak pozostałe wykładniki „samooszustwa”, przesąza możliwość zdobycia odpowiedniej wiedzy przez agensa. Wspomniany efekt widoczny był już przy czasowniku okłamywać się, że [p]. Właściwość ta uwidaczniała się w zestawieniu predykatu $z$ fraza: bo nic na to nie wskazywało. Ten sam efekt sprzecznościowy zaobserwujemy przy autorefleksywnym wmówić.

Zdanie łaczace orzeczenie o wiedzy agensa $z$ użyciem czasownika wmówić sobie, że [p], podobnie jak w wypadku wcześniej opisywanych jednostek, jest niesprzeczne: 'Wiedzac // stwierdziwszy, że Anna ma romans, Aleksiej wmówił sobie, że jest mu wierna. Oznacza to, że świadomość lub wiedza, jak się rzeczy maja, nie przeszkadza, by wmawiać sobie coś zgoła przeciwnego. Czasownik wmówić sobie presuponuje wielokrotny akt mówienia nieasertorycznego skierowanego do siebie samego. Nie określa natomiast stanu wiedzy agensa. To metanadawca w części rematycznej znaczenia jednostki kwalifikuje powiedzenie agensa jako fałszywe oraz przesądza gotowość podmiotu do działania $z$ uwzględnieniem fałszywego stwierdzenia.

Opis słownikowy czasownika wmówić - wmawiać sobie, że [p] przynosi dwie kwestie wymagające rozstrzygnięcia. Pierwsza $z$ nich to pytanie o to, czy predykat wmówić // wmawiać sobie, że [p] jest odrębnym bytem językowym (tak sugeruje zapis WSJP), czy też jednym $z$ typów użyć jednostki wmówić // wmawiać komuś, że [p] (tak rozstrzygaja tę kwestię m.in. ISJP, SJPD). Trzeba zatem ustalić językowy status autorefleksywnego wmówić. Drugie pytanie wiąże się $z$ propozycjami opisu treści tego czasownika. $Z$ glosy prezentującej treść jednostki zamieszczonej w ISJP dowiadujemy się, że wmówić coś komuś (lub sobie), to „przekonać go, że coś nie jest prawda, wielokrotnie mówiąc mu to". Podobnie znaczenie czasownika wmawiać - wmówić opisywane było w SJPD: „usposabiać kogo do uwierzenia czemuś; skłaniać kogoś do uznania za prawdę czegoś nieprawdziwego”. Podobna definicję znajdujemy w USJP: „umacniać się w niesłusznym przekonaniu o czymś, sugerować coś sobie". Z kolei WSJP definiuje wmówić sobie następująco: „wywołać w sobie przekonanie, że coś jest prawdą, bez względu na stan rzeczywisty”. Opis ten niewiele różni się od objaśnienia znaczenia okłamywać się, że [p]. 
O odrębności językowej wyrażeń zawierających tę samą formę językową świadczy regularne zróżnicowanie semantyczne dające się zaobserwować przy poszczególnych typach użyć. Czy z taka sytuacją mamy do czynienia przy wmówić komuś i wmówić sobie? Wmówić [komuś] w odróżnieniu od wmówić sobie implikuje wprowadzenie kogoś w błąd oraz kłamstwo, por. *Anna wmówiła Aleksiejowi, że nie ma romansu, ale nie wprowadziła go w błąd // *Anna, która wmówiła Aleksiejowi, że ma romansu, nie skłamała. Żadna $z$ tych zależności leksykalnych nie zachodzi w wypadku wmówić sobie, że [p]. Zarówno kłamstwo, jak i wprowadzenie w błąd zakładaja świadomość agensa co do prawdziwości pewnej askrypcji, tymczasem wmówienie sobie czegoś, jak widzieliśmy, tego nie zakłada; por. Aleksiej wmówił sobie, że Anna nie ma romansu. ${ }^{+} \mathrm{Nie}$ skłamał jednak // +Aleksiej wmówit sobie, że Anna nie ma romansu, lecz nie został wprowadzony $w$ bład. Wygląda więc na to, że autorefleksywne wmówić j e s t odrębnym bytem języka.

Pozostaje jeszcze rozważyć hipotezy dotyczące treści wmówić sobie, $\dot{z} e$ [p]. Główna intuicja semantyczna w opisie leksykograficznym koncentruje się wokół pojęcia 'bycia przekonanym'. ${ }^{10}$ Czasownik wmówić sobie, że $[p]$ nie implikuje tego, że ktoś przekonał sam siebie, że zachodzi to, o czym mowa w zdaniu podrzędnym. Przekonanie kogoś lub samego siebie zakłada, jak pisałam, rozważanie przeciwstawnych racji. Wmawiając coś sobie, nie bierzemy pod uwagę faktów.

Wattpliwe jest także istnienie relacji logicznej między 'wmówieniem sobie czegoś' i 'byciem przekonanym co do tego', por.: Aleksiej wmówił sobie, że Anna nie ma romansu, nie był jednak przekonany, że jest mu wierna. Wygląda na to, że ten, kto sobie coś wmawia, nie musi być przekonany, że tak właśnie jest. Jeśli dokładniej przyjrzymy się układowi złożonemu $z$ obu predykatów, okaże się, że wmówienie sobie czegoś wyklucza 'bycie przekonanym, że jest tak a tak'. Wmawiamy sobie coś wtedy właśnie, gdy nie jesteśmy czegoś pewni lub przekonani do czegoś. Odzwierciedla się to w sprzeczności następującego układu słownego: *Aleksiej wmówił sobie, że Anna nie ma romansu i był przekonany, że tak właśnie jest. Widać, że wmówienie sobie czegoś i rozważanie pewnej

$10 \mathrm{~W}$ opisie słownikowym znajdujemy kilka sformułowań nawiazujących do tego pojęcia, mianowicie wzbudzić przekonanie, że... lub przekonać siebie, że... Każde $z$ tych sformułowań ma swoja specyfikę. Na przykład pierwsze $z$ nich - wzbudzić przekonanie należy do stylu książkowego, podczas gdy definiendum jest wyrażeniem neutralnym. Druga $z$ fraz wykorzystywanych w objaśnieniach słownikowych - przekonać siebie, że [p] jest używana najczęściej w odniesieniu do czynności nieskutecznej w sformułowaniach typu: chciał // próbował przekonać siebie. Tymczasem wmówić sobie, że [p] jest implikatywne negatywnie. W swojej analizie wykorzystuje jednostkę być przekonanym, że [p], która odpowiada pod tym względem dokonanemu wmówić sobie, że [p]. Niemniej wnioski co do zależności między definiendum a wymienionymi wykładnikami 'przekonania' będą takie same. 
alternatywy zdań (stanowiące założenie logiczne 'bycia przekonanym, że tak a tak') nie idą w parze. Nie o zwiększenie puli własnej wiedzy chodzi temu, kto sobie coś wmawia.

O czym zatem, skoro nie o wewnętrznym przekonaniu podmiotu, mówi rozważana jednostka? Czym różni się ona od okłamywania się lub zwykłej pomyłki? Sednem znaczenia wmówić sobie, że [p] jest gotowość podmiotu do postępowania zgodnego $z$ askrypcja ujęta $\mathrm{w}$ zdaniu podrzędnym wprowadzanym przez predykat. Istotnym elementem pojęciowym wchodzacym w skład treści tej jednostki jest też 'wielokrotny akt mówienia nieasertorycznego'11. Użycie wmówić sobie, że [p] implikuje fałsz askrypcji wypowiadanej przez tego, o kim mowa, a także istnienie znanych mu okoliczności, które świadczą o fałszywości zdania podrzędnego.

Wmawianie sobie różni się od okłamywania się powtarzalnością aktu mowy skierowanego do samego siebie, a także brakiem przesądzenia co do ignorancji podmiotu obejmującej wycinek rzeczywistości, o którym mowa w zdaniu podrzędnym. Treść tego predykatu jest bardziej precyzyjna. Dlatego też to wmówić sobie implikuje okłamywać się, a nie na odwrót. Od pomyłki wykładniki 'samooszustwa' różnią się przede wszystkim implikacją wiedzy podmiotu o okolicznościach wykluczających prawdziwość askrypcji ujętej w zdaniu podrzędnym, a także wspólną pozostałym wykładnikom negatywna oceną wpisaną w treść predykatu; por.: *Aleksiej słusznie wmówił sobie, że Anna nie ma romansu.

Trudno oprzeć się pokusie zapytania o sens wmawiania sobie czegoś. Ulegaja jej psychologowie i filozofowie, którzy poszukują uzasadnienia tego rodzaju strategii, zwłaszcza jeśli osoba, o której mowa, mówi coś również w trybie asertorycznym, a inne jej działania uwzględniają fakty. Sam predykat, by tak rzec, milczy o powodach wmówienia sobie czegoś.

\section{WYKEADNIKI „SAMOOSZUSTWA” A ISTOTA FENOMENU}

Pora wrócić do pytania o istotę „samooszustwa”. Do której z interpretacji skłaniaja nas obserwacje faktów lingwistycznych? Na gruncie polszczyzny wykładniki mówiące o fałszu askrypcji, która w akcie nieasercyjnego mówienia skierowanego do samego siebie prezentuje agens, nie implikują kłamstwa ani wprowadzenia w błąd. Tym właśnie ich właściwości semantyczne różnią się od treści ich odpowiedników adresatywnych. Wygląda więc na to, że „samooszustwo" nie sprowadza się ani do oszustwa, ani do kłamstwa, ani też do celowego wprowadzania w błąd. Rację zatem należałoby przyznać zwolennikom interpretacji antyredukcjonistycznej.

11 Przypomnę, że mówiąc o akcie mowy, mam na myśli nie tylko wypowiedzi wygłoszone do kogoś, ale także sytuacje określane mianem mowy wewnętrznej. 
Za antyredukcjonistyczna interpretacja „samooszustwa” przemawia również to, że jego potencjalne wykładniki nie przesądzają uprzedniej wiedzy podmiotu co do stwierdzenia ujętego w przyłączonej askrypcji, choć jej nie wykluczają. Można zatem wmówić sobie coś, o czym wiemy, że nie jest faktem. Ktoś, kto wmówił sobie coś, okłamuje lub oszukuje się, że jest tak a tak, działa zgodnie ze stwierdzeniem, które metanadawca określa jako fałszywe. Nie jest jednak tak, iżby żywił dwa sprzeczne przekonania, gdyż albo nie wie, jak się rzeczy mają, albo wie, choć nie uwzględnia tego w swoim działaniu.

\section{Słowniki}

ISJP: M. Bańko (red.), 2000, Inny słownik języka polskiego, t. 1-2, Warszawa.

SJPD: W. Doroszewski (red.), 1958-1969, Słownik języka polskiego, t. 1-11, Warszawa.

USJP: S. Dubisz (red. nauk.), Uniwersalny słownik języka polskiego, https:// sjp.pwn.pl [dostęp: 02.09.2020 r.].

WSJP: P. Żmigrodzki (red.), Wielki słownik języka polskiego, http://wsjp.pl/ [dostęp: 23.05.2020 r.].

\section{Bibliografia}

K. Beier, 2019, Lying and self-deception [w:] J. Meibauer (red.), The Oxford Handbook of Lying, Oxford, s. 203-213.

A. Bogusławski, 1988, Język w słowniku. Desiderata semantyczne do wielkiego słownika polszczyzny, Warszawa.

A. Bogusławski, 2004, Remarks on quotative 'saying', „Studies in Polish Linguistics" 1, s. 29-45.

A. Bogusławski, 2005, Do teorii czasownika powiedzieć, „Polonica” XXIV, s. $113-129$.

A. Bogusławski, 2007, A Study in the Linguistics-Philosophy Interface, Warszawa.

A. Bogusławski, 2008, Semantyka, pragmatyka. Leksykografa głos demarkacyjny, seria „Semiosis Lexicografica” XLVIII, Warszawa.

A. Bogusławski, M. Danielewiczowa, 2005, Verba Polona Abscondita. Sonda słownikowa III, Warszawa.

W. Chudy, 2003, Filozofia kłamstwa, Warszawa.

M. Danielewiczowa, 2002, Wiedza i niewiedza. Studium polskich czasowników epistemicznych, Warszawa.

D. Davidson, 2004, Deception and Division [w:] tegoż, Problems of Rationality, Oxford Scholarship Online, s. 199-212; DOI:10.1093/0198237545.001.0001

Z. Greń, 1994, Semantyka i składnia czasowników oznaczajacych akty mowy w języku polskim i czeskim, Warszawa.

J. Kucharski, 2014, Usprawiedliwione kłamstwo we współczesnej etyce stosowanej, Kraków.

M. Marcjanik, 1987, Polskie czasowniki adresatywne. Pragmatyka, semantyka, składnia, Kielce. 
R. Piłat, 2013, Oszukiwanie samego siebie [w:] tegoż, Powinność $i$ samowiedza. Studia z filozofii praktycznej, Warszawa, s. 93-122.

O. Tumski, 2012, Dwunasta warstwa, wydawnictwo internetowe e-bookowo.pl

J. Wajszczuk, 1997, System znaczeń w obszarze spójników polskich. Wprowadzenie do opisu, Warszawa.

\title{
On the so-called samooszustwo (self-deception) in light of the meanings of selected verbs
}

\begin{abstract}
Summary
This paper is dedicated to the analysis of semantic properties of three Polish verbs: okłamywać się, że [p] (to lie to oneself that [p]), oszukiwać się, że [p] (to deceive oneself that [p]) and wmówić/ / wmawiać sobie, że [p] (to convince oneself that $[p]$. The author presents arguments in favour of the thesis that these are separate lexical units, which cannot be reduced to appropriate addressative verbs. In their semantic structure, she distinguishes, apart from the agent (epistemic subject), also the position of the controller-sender (metasender), and uses a conceptual distinction between quotative speech (present in the structure of the examined units) and assertoric speech in her analysis. By clashing the properties of Polish exponents of 'samooszustwo' (self-deception) and two competing types of philosophical interpretation of the phenomenon, the author supports anti-reductionist approaches, which do not identify self-deception with a lie or deception. She emphasises that none of the lexical exponents referring to this phenomenon implies 'oszustwo' (a deception) or 'kłamstwo' (a lie). None implies such a characteristic of the agent as is a sine qua non condition for the occurrence of any of the two situations either. From the perspective of language, 'samooszustwo' (self-deception) is not deception. It is a kind of an irrational action that is inconsistent with the agent's knowledge.
\end{abstract}

Keywords: semantics - 'samooszustwo' (self-deception) - 'kłamstwo' (a lie) - falsehood verbs - okłamywać się, że [p] (to lie to oneself that [p]), oszukiwać się, $\dot{z} e[p]$ (to deceive oneself that [p]) and wmówić/wmawiać sobie, że [p] (to convince oneself that [p])

Trans. Monika Czarnecka 